\title{
Pharmacognostic Study of Sorghum bicolor (L.)
}

\author{
Fofie Yvette Bra N'guessan ${ }^{1}$, Coulibaly Kiyinlma ${ }^{2}$, Kone-Bamba Diénéba ${ }^{3}$ \\ ${ }^{1,3}$ UFR Sciences Pharmaceutiques et Biologiques, Université Félix Houphouët Boigny de Cocody-Abidjan; 22 BP 747 Abidjan 22 , Côte \\ d'Ivoire
}

${ }^{2}$ UFR des Sciences Biologiques, Université Péléforo Gon Coulibaly, BP 1328 Korhogo, Côte d'Ivoire

\begin{abstract}
Objective: To study the preliminary characteristics and pharmacognostic of Sorghum bicolor (L.) cereal used as food in some parts of West Africa. Methods: The pharmacognosic study involved performing macroscopic and microscopic examination of fresh and dry medicinal plant. The study of physicochemical parameters consisted of the determination of moisture content, total ash and insoluble sulfur in hydrochloric acid. Results: The pharmacognosic examination of this plant has revealed morphological examination revealed an annual grass crop height can reach up to $1 \mathrm{~m}$ to $5 \mathrm{~m}$ high. The cylindrical and solid stem, which is usually erect, carries a terminal inflorescence in a compact panicle. It includes spikelets of one or two bisexual flowers. The micrograph showed many large translucent tissue structures. These are the endocarp, the aleurone layer and the integuments. Conclusion: pharmacognosic analysis and physico-chemical characteristics can help the pharmacopoeia for the efficient utilization of this plant.
\end{abstract}

Keywords: Pharmacognosy, nutraceuticals, Sorghum bicolor (L.)

\section{Introduction}

Medicinal plants are of great importance to human health. This is why the World Health Organization estimates that $80 \%$ of the population in developing countries relies on traditional medicine for their primary health care [1]. Therefore, medicinal plants play important role in the sociocultural and therapeutic needs of peoples. Some of these plants are used as spices and foods [2; 3], also serve as a resource for research and development of new drugs [4]. In Africa and elsewhere, several ethnobotanical surveys conducted, showed that Sorghum bicolor (L.). is a medicinal plant well known and widely used in the treatment of various infections.

Sorghum bicolor is a Poaceae grown in Africa. It is in the north-east of Africa that we find the greatest diversity of species of the genus Sorghum among both cultivated and wild types. Sorghum bicolor formerly known Sorghum vulgare includes wild weeds and annual cultivated types that are completely infertile (5). It is a plant that is characterized by a strong root system, which largely explains its ability to withstand drought. This species is grown either for its grain, fodder or for its stems (6). However, there is another type of sorghum, the sorghum dye which is extracted from a bio-dye mainly leaf sheaths (7). Sorghum bicolor (L.) Moench. is a very important crop in the tropical region. The seeds make up the composition for treatment of gonorrhea and cough in Senegal. The decoction of the bark associated with Pterocarpus erinaceus (Fabaceae) is used in the treatment against anemia. The decoction of stems, mixed with lemon, is used in the treatment of jaundice in Togo and Niger. The red pigment, which have antimicrobial and antifungal properties, also serves as a remedy for anemia in traditional medicine.. In Ethiopia, the seeds of Sorghum bicolor (L.) Moench. are used for the treatment of diarrhea (8). Although Sorghum bicolor is known for its nutritional value, it is also used for some medicinal properties. Thus, sorghum dye is used in infusion to treat anemia and certain menstrual disorders (7).
The red pigment of sorghum, having antifungal and antimicrobial properties, is used in traditional medicine in Africa (7). Despite scientific and medical values proven by several studies on this Sorghum bicolor L. drugs, analyzes of pharmacognosy and study of physicochemical parameters like moisture content, total ash, ashes insoluble in sulfuric and hydrochloric acid, are very few. Therefore, this study reported, anatomical and micrographic examination of plant and dried drug; and a study of physicochemical parameters of drug ;moisture content, total ash, ashes insoluble in sulfuric and hydrochloric acid.

\section{Materials and Methods}

\subsection{Plant Material}

The plant material consisted of dried fruit of Sorghum bicolor (L.) Moench. They were purchased from the market in Abidjan. A herbarium of drug was formed and deposited at the National Floristic Center of the Félix HouphouëtBoigny University Abidjan.

\subsection{Methods}

The drugs were cleaned and dried away from sunlight under laboratory temperature $\left(24^{\circ} \mathrm{C}-26^{\circ} \mathrm{C}\right)$. The drugs were roughly pulverized using a grinder Retsch SM 2000. Powdered drug was used for the pharmacognosic study and physico-chemical screening.

\subsection{Macroscopic Studies}

The macroscopic study is a morphological study. This study allowed us to make a description of the plant and determine the shape, texture and color of the drug

\subsection{Organoleptic characteristics study}

The study of the organoleptic characteristics covered the powdered drug and concerned the taste, appearance, color and odor of drugs. The smell test was carried out with $1 \mathrm{mg}$ of powdered drug taken between thumb and forefinger. The

Volume 6 Issue 1, January 2017 


\section{International Journal of Science and Research (IJSR) \\ ISSN (Online): 2319-7064}

Index Copernicus Value (2015): 78.96 | Impact Factor (2015): 6.391

odoriferous constituents released slowly and were tested repeatedly. The intensity of the odor was first tested by the following parameters: "No, low, sharp and strong ". Then was determined the odor type "Aromatic, Fruity".

For taste, five (5) grams of drugs were placed and kept in the mouth without swallowing, for ten (10) to thirty (30) seconds. After expectorating the sample, the mouth was rinsed and then enjoyed the taste: "Piquant, Fade, sour, bitter, Sweet, Salty, warm." This important study allows for the identification of the drug and its standardization.

The appearance and color was noted through observation.

\subsubsection{Micrographic Study}

A small amount of fine powder was mixed with a few drops of $5 \% \mathrm{KOH}$ placed on an object holder blade and then covered with a coverslip. The observation was conducted under an optical microscope with the $10 \mathrm{x}$ objective. The drug powder characteristic elements were noted and photographed.

\subsection{Physicochemical Study}

The study of physicochemical parameters involved determining the moisture content and ash content it was conducted using the following process:

\subsubsection{Determination of moisture content}

The determination of the water content was performed by the gravimetric method according to the protocol created by Linden and Lorient [9] and Mukherjee [10]: 5 tests were performed taken $5 \mathrm{~g}$ of powder introduced into 5 calibrated crucibles. The 5 samples were dried in an oven at $105{ }^{\circ} \mathrm{C}$ for 24 hours. The crucibles were cooled in a desiccator and weighed. The masses obtained were used to calculate the mass loss and calculate the water content of the powder as a percentage.

\subsubsection{Determination of ash content}

2.5.2.1 Total ash: The dried powder used for the determination of the moisture content was reduced to ashes in a furnace at $600{ }^{\circ} \mathrm{C}$ for 6 hours. After cooling in a desiccator, the ashes were weighed. The weights obtained were used to calculate the masses of ash and calculate the total ash content, expressed as a percentage.

\subsubsection{Determination of acid insoluble ash value in $10 \%$ hydrochloric acid:}

Total ash obtained was mixed with $20 \mathrm{ml}$ of $10 \%$ hydrochloric acid. The whole mixture was boiled in a water bath for 15 minutes. The solution obtained was filtered through Whatman paper. The residue was collected in a crucible and calcined in an oven at $600{ }^{\circ} \mathrm{C}$ for 6 hours. The crucible was cooled in a desiccator. The mass of insoluble ash in hydrochloric acid was expressed as a percentage.

2.5.2.3 50\% Sulfuric ashes: Five tests were performed taken $5 \mathrm{~g}$ of powder, introduced into crucibles. It was added to the contents of each crucible $5 \mathrm{ml}$ of $50 \% \mathrm{H}_{2} \mathrm{SO}_{4}$. The solution was placed in an oven at the temperature of $600{ }^{\circ} \mathrm{C}$ for 6 hours. After calcinations and cooling in a desiccator, the ash was weighed and the mass of sulfuric ash was expressed as a percentage.

\section{Results}

\subsection{Macroscopic Study}

This study allowed us to identify the plant material, and is the first step in the characterization of the crude drug.

\section{Morphological characteristics}

It is an annual grass crop growing up to $1 \mathrm{~m}$ to $5 \mathrm{~m}$ high. The stem (culm) cylindrical and compact, usually in erected position carries a terminal inflorescence compact panicle. This includes one or two spikelets bisexual flowers. The leaves are simple and alternate. The leaf blade flat or wavy edges, is lanceolate or linear-lanceolate. It stands erected in the beginning and later folds. $60 \mathrm{~cm}$ long inflorescences are terminal panicle.

Sorghum bicolor (L.) Moench. has two types of flower. The lower flower is made solely of a lemma, and the upper flower bisexual, consists of a lemma slit at the apex. The fruits are caryopses (grain), usually partially covered by glumes, 4-8 $\mathrm{mm}$ in diameter, rounded and blunt point.

\section{Phytogeography}

Sorghum bicolor (L.) Moench. is a species found in the tropical, subtropical and warm temperate regions. This species naturally occupies a vast area extending from the northeast tropical Africa to the whole of Africa and the Middle East to India. This plant is exotic in China, Southeast Asia, in the Americas, Australia, Europe, Argentina and Russia.

\subsection{Ecology}

Sorghum bicolor (L.) Moench. is a perennial plant and can be harvested several times a year. However, it is treated as an annual. This species has many cultivars, highly polymorphic and grown in the tropics and subtropics. It is grown along coastal waterways. Sorghum bicolor (L.) Moench. develops a long and deeper roots therefore tolerate drought. It can be found on any type of soil and is not found in the wild nature.

\section{Specimens studied}

Korhogo, in February 2012, Fofié No. 03, Korhogo, October 1992 Poilecot No. 4724.

Table 1: Tasting the fruits of Sorghum bicolor (L.) Moench

\begin{tabular}{|c|c|}
\hline Drug character's & Sorghum bicolor (L.) Moench \\
\hline Taste & Neutral taste \\
\hline Odor & No odor \\
\hline Color & Pink \\
\hline Aspect & Powdery \\
\hline Texture & Coarse \\
\hline
\end{tabular}

All the organoleptic characteristics found in this study are shown in Table I. 


\section{International Journal of Science and Research (IJSR) \\ ISSN (Online): 2319-7064}

Index Copernicus Value (2015): 78.96 | Impact Factor (2015): 6.391

\subsection{Physicochemical study}

This study is very important in that it helps identify poor handling practices and assess the quality of the drug under study. Various parameters were defined and recorded in Table 2 .

Table II: Physicochemical Parameters of Sorghum bicolor (L.) Moench

\begin{tabular}{|c|c|c|c|c|}
\hline $\begin{array}{c}\text { Parameters } \\
\text { of Drug }\end{array}$ & $\begin{array}{c}\text { Humidity } \\
\%\end{array}$ & $\begin{array}{c}\text { Total } \\
\text { ash \% }\end{array}$ & $\begin{array}{c}\text { Sulfuric } \\
\text { ash \% }\end{array}$ & $\begin{array}{c}\text { Insoluble ash in } \\
\text { hydrochloric acid \% }\end{array}$ \\
\hline Sorghum & $12.95 \pm$ & $1.34 \pm$ & $1.79 \pm$ & $1.98 \pm 0.07$ \\
bicolor (L.) & 0.02 & 0.02 & 0.03 & \\
NDF & & & & \\
\hline
\end{tabular}

\section{Discussion}

Our study, has focused on examining pharmacognosic study of Sorghum bicolor fruits (L.) .The scientific literature has allowed us to review a large number of bibliographic data on this drug, including the systematic and various domestic uses in traditional medicine. The performance of macroscopic and microscopic studies of Sorghum bicolor (L.) remains essential to identify the authenticity of this drug and in other to prevent falsification.

The organoleptic characteristics are very important in drugs because they play a role in distinguishing adulterated or substituted drug from the authentic drug [11]. The Sorghum bicolor (L.) Moench drug, when crushed is powdery in appearance, pink color, has no odor. It has a neutral taste.

The micrograph performed on the drug powder allowed to highlight a number of characteristics elements including: Sclerosing cell pericarp, Endocarp; Aleurone layer; Tegument; Young sclerosing cell pericarp has many large translucent tissue structures. These are the endocarp, the aleurone layer and the integuments (12)

The study of physicochemical parameters such as moisture content and ash values are useful; to determine the physiological and non-physiological state of ash, to detect the possibility of microbial growth or contamination and finally the presence of impurities. In this study, the drug of S. bicolor (L.) Moench. is constituted by the non-dehulled fruit NDF (and its by-products). Its moisture content was $12.95 \%$.

The study of sorghum fruit revealed that the hulled fruit has a slightly lower moisture content $(12.19 \%)$ than the nondehulled fruit. These values are greater than $10 \%$ and also those found by BALOLE et al. (2006). These high moisture content, however, remain below the standard indicated by the Codex Alimenterius (15\%) (14). This high contents could be due to the hygrometric degree and the drying temperature on one hand and on the other hand, the high moisture content in the unhulled fruit may be due to the presence of abundant mucilage used to store water. The water content, which is less than or equal to the standards, gives the pulverized drugs a better long-term conservation property.
The measurement of total ash gave us a rate of $1.34 \pm 0.02$. This value, indicated the level of minerals in the drug [15] .The sulfuric ash value was $1.79 \pm 0.03$. They result from the conversion of organic salts to sulfates [15]. The ash insoluble in hydrochloric acid gave a rate of $1.98 \pm 0.07$. Indeed, insoluble ash in hydrochloric acid tells us about the contamination of the drug by siliceous elements [15].

\section{Conclusion}

This study allowed us to detect the presence of different pharmacognosic parameters in Sorghum bicolor (L.) drug according to botanical standard and WHO guidelines. The value of moisture content found is satisfactory as the moisture content level in the drug studied allows good conservation and prevents oxidative reactions, fermentation and microbial growth In light of these results, pharmacognostic analysis and physicochemical characteristics can help in the efficient utilization of this plant as part of a standardization policy, identification and research on Sorghum bicolor (L.) drugs.

\section{Acknowledgement}

We would like to extend our profound gratitude to the entire staff of Laboratory of Pharmacognosy Faculty of Pharmaceutical and Biological Sciences of the Felix Houphouet Boigny University for their technical support during the performance of this work.

\section{References}

[1] Nathiya S., Santhi N. and Kalaiselvi S., 2012. A comparative study on ontogenic expression of antioxydants and secondary metabolites in Withania somnifera. Int Res. J. pharm; 3(1): 2010-2015.

[2] Okwu D. E. 1999. Flavouring Properties of Spices on Cassava Futu. Afr. J. Roots and Tuber crops 3 (2): 1921.

[3] Okwu, D. E. 2001. Evaluation of the chemical composition of indigenous spices and flavouring Agents. Gl. J. of Pure and appl. Sc. 7 (3): 455-459.

[4] Kong J. M. Goh N. K., Chia L. S and Chia T. F. 2008. Recent Advances in Traditional Plant Drugs and Orchids. Acta Pharm. Sc. 24: 7-21.

[5] Anonyme 6, 2014. Sorghum. (Consulté en Février 2014)

$<$ http:/database.prota.org/PROTAhtml/Sorghum\%20bi colorfr.htm $>$

[6] Anonyme 7, 2014. Final 2012 Data and Preliminary 2013 Data for 5 major commodity aggregates. (Consulté en Février 2014)

[7] Kayodé AP, Nout MJ, Linnemann AR, Hounhouigan JD, Berghofer $E$ et Siebenhandl-Ehn S, 2011. Uncommonly high level of 3deoxyanthocyanidins and antioxidant capacity in the leaf sheaths of dye Sorghum. Journal of Agricultural and Food Chemistry, 59(4): 1178-1184.

[8] Neuwinger HD, 2000. African traditional medicine: a dictionary of plant use and applications. Medpharm Scientific, Stuttgart, Germany.589 p. 


\section{International Journal of Science and Research (IJSR) \\ ISSN (Online): 2319-7064 \\ Index Copernicus Value (2015): 78.96 | Impact Factor (2015): 6.391}

[9] Linden G., Lorient D., 1994. Biochimie agroindusrielle. Ed. Masson, Paris. 360 p.

[10] Mukherjee P. K., 2002. Quality control of herbal drugs, $1^{\text {st }}$ éd., Busness horizon, New Delhi, 356: 187195

[11] Kumar S., Kumar V., Prakash O., 2011. Microscopic evaluation and physicochemical analysis of Dillenia indica leaf. Asian Pac J. Trop. Biomed; 1: 337-340.

[12] Awika JM, Rooney LW et Waniska et RD, 2004. Sorghum phytochemicals and their potential aspects on human health. Journal of Agricultural and Food Chemistry.52: 4388.
[13] Balole, TV et Legwaila GM, 2006. Sorghum bicolor (L.) Moench. In: Brink, M, Belay, G Ed. et PROTA 1: Cereals and pulses/Céréales et légumes secs. [CDRom]. PROTA, Wageningen, Pays Bas. $<$ http://fr.wikipedia.org/wiki/Sorgho_commun $>$

[14] FAO Rome, 1995. Le sorgho et les mils dans la nutrition humaine. FAO, Rome. (Consulté le 1705 2014) http://www.fao.org/docrep/t0818f/T0818F01.htm

[15] Srikanth K., Vikram G., Archana P., Rajinikanth M., and Rama S. N., 2013. Pharmacognostic and phytochemical investigations in Strychnos potatorum Linn. F. J. of Pharm. and phyt., 2 (4): 46-51.

\section{Micrography}

The micrography made it possible to highlight the following elements, photographed:

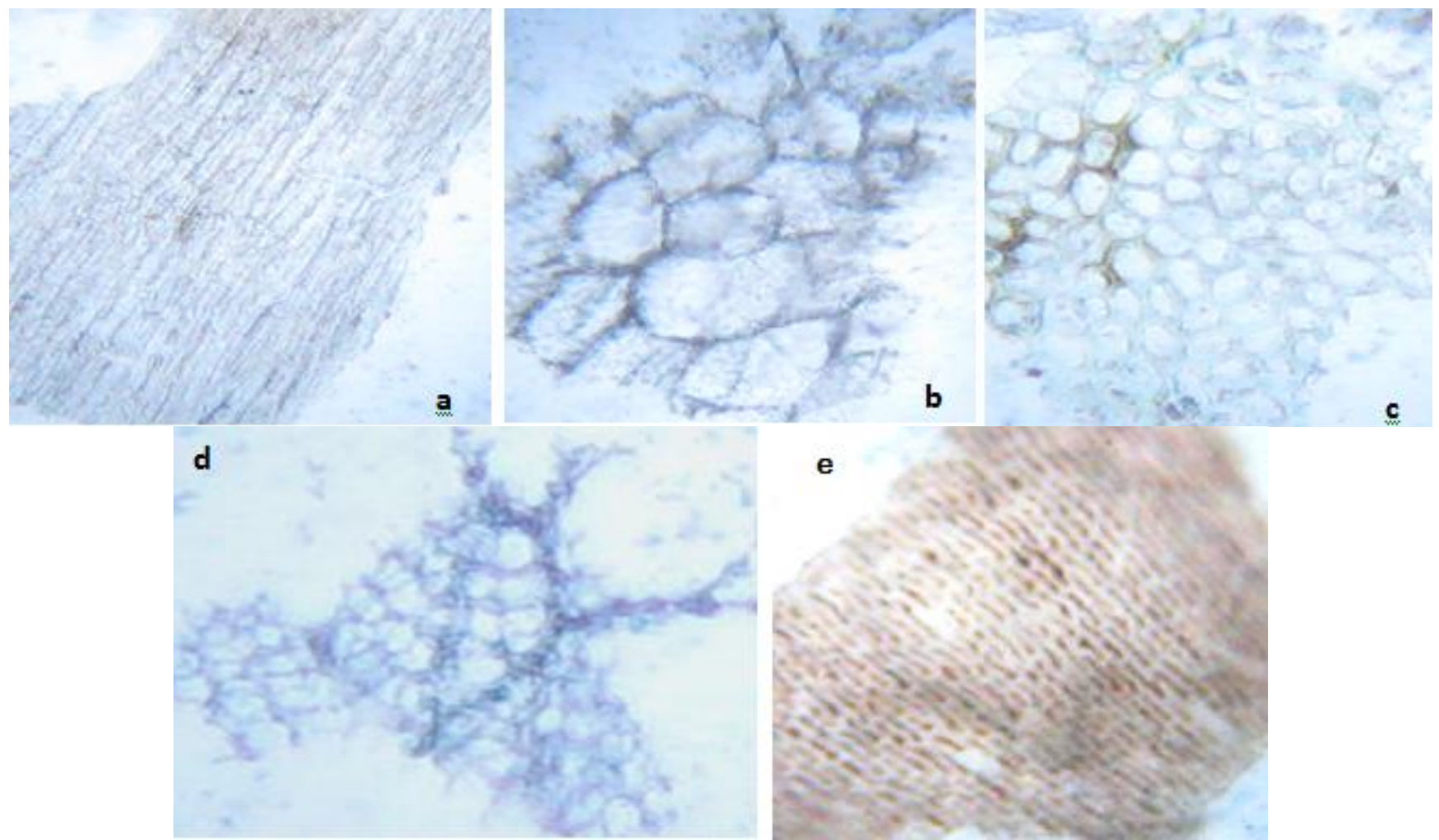

Figure 1: Micrography of the powder of the fruits of Sorghum bicolor (L.) Moench. (Source : FOFIE Yvette) 1a. Sclerosing cell pericarp; 1b. Endocarp; 1c. Aleurone layer; 1d. Tegument; 1e. Young sclerosing cell pericarp 


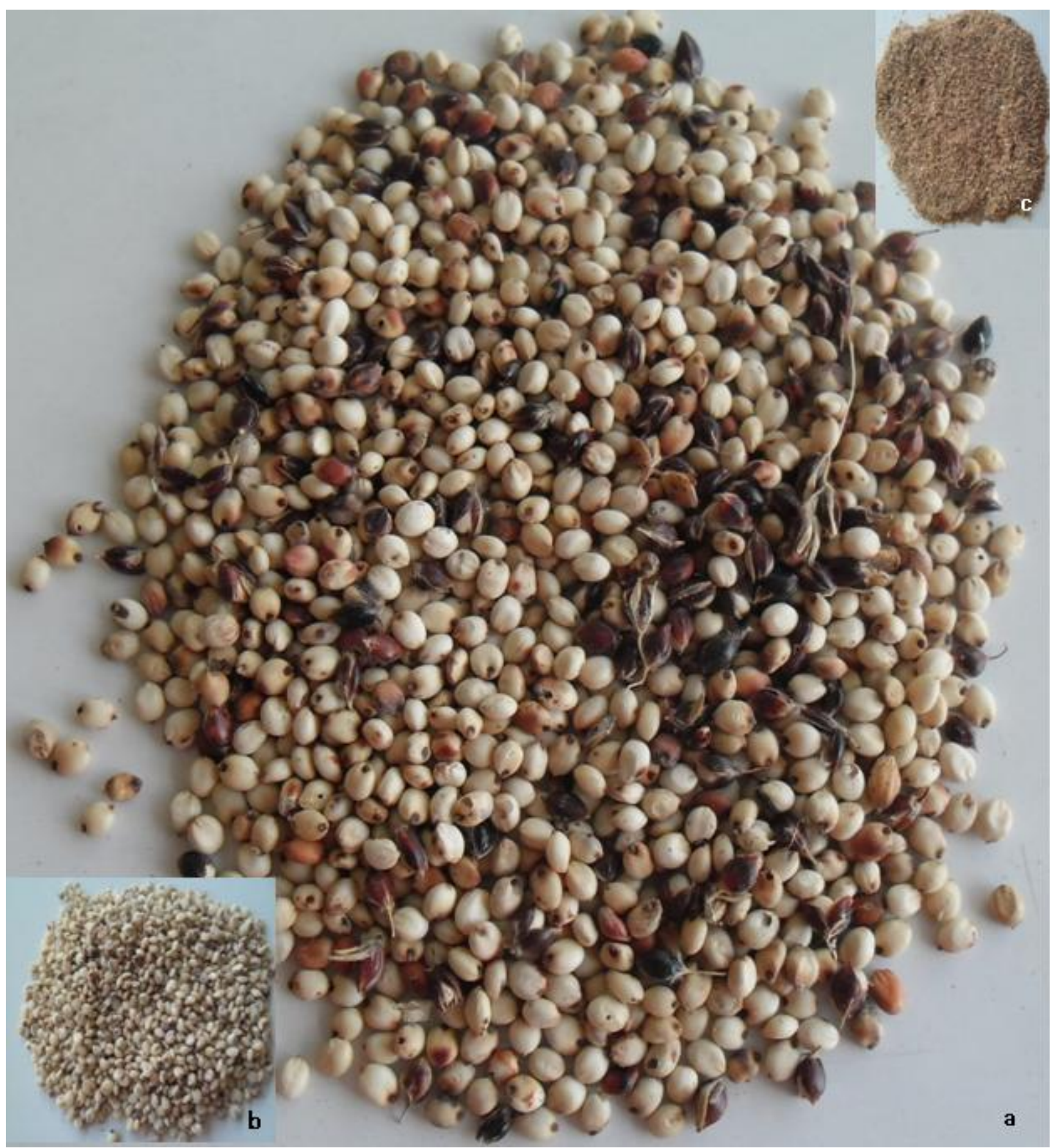

Figure 2: Fruits of Sorghum bicolor (L.) Moench. Source : FOFIE Yvette

2a.Non-dehulled fruits; 2b. Fruits shells; 2c. Bran obtained from the shell of fruits

Volume 6 Issue 1, January 2017 www.ijsr.net 


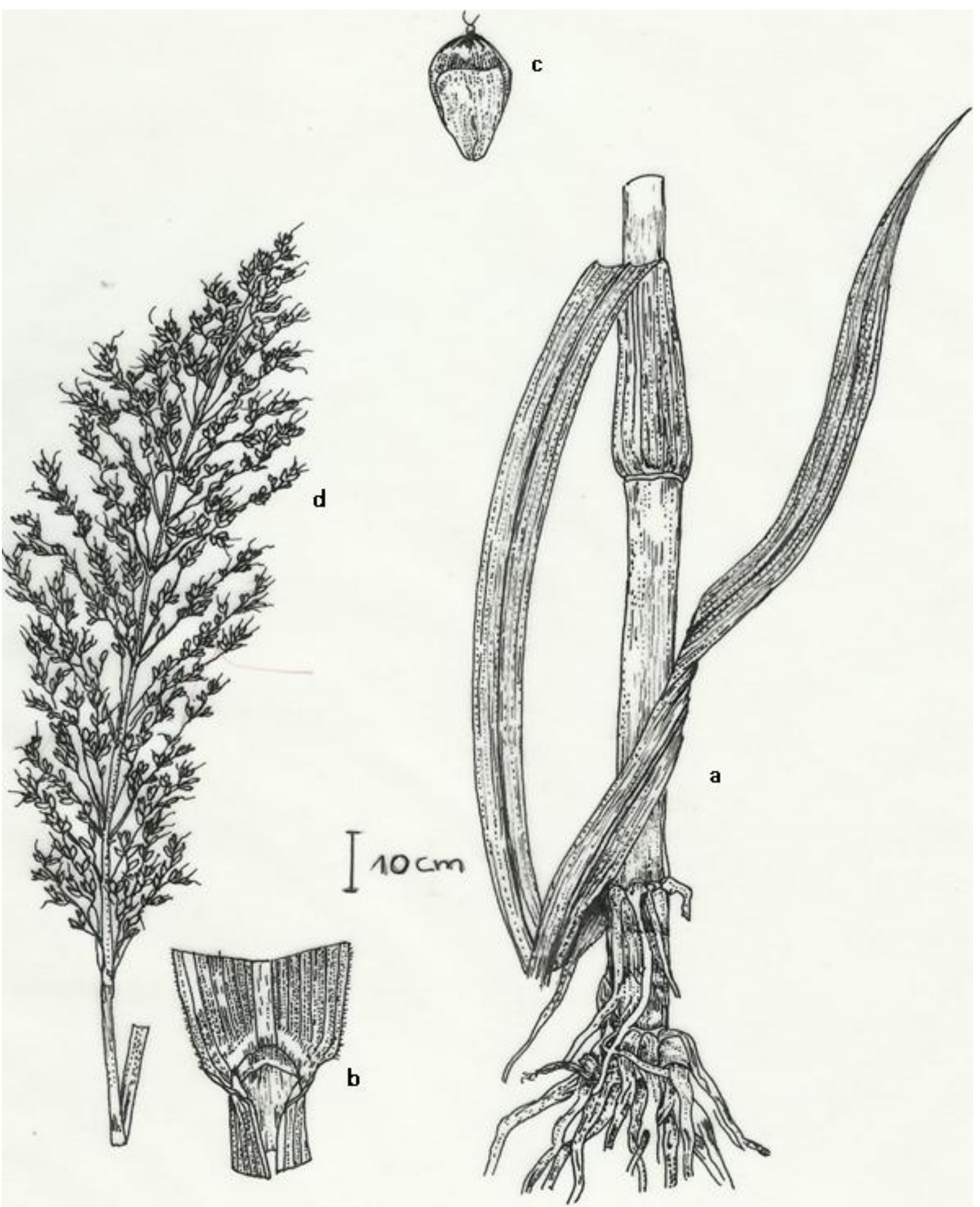

Figure 3: Different parts of Sorghum bicolor (L.) Moench. (Source : FOFIE Yvette) a. Plant Stem b. Leaf sheath C.Fruit d. Fruiting shoot 